Egyptian J. of Nutrition Vol. XXXV No. 1 (2020)

\title{
Physicochemical and sensorial characterization of gluten-free cupcakes
}

\author{
Enayat M. Hassan, , Hany A. Fahmy, ${ }^{*}$ Shimaa Magdy ${ }^{\star \star}$ and \\ Magda I. Hassan* \\ ${ }^{*}$ Food Science Dep., Faculty of Agriculture, Cairo \\ University,Egypt \\ ${ }^{*}$ Special Food and Nutrition Dep., Food Technology \\ Research Institute (FTRI), Agriculture Research Center,Egypt
}

\begin{abstract}
Nowadays, there is a growing need for gluten-free bakery products. So, the aim of this study was to develop acceptable glutenfree cupcakes using pearl millet, rice and corn flours for patients with celiac disease. Gluten free cupcakes (with or without cocoa) were evaluated chemical, antioxidant, physical and sensorial properties. The results showed that sample (2) (100\% millet flour) had the highest values of protein, fat, ash, $\mathrm{Ca}, \mathrm{Fe}, \mathrm{Zn}$, vitamins (A, E, B1, B3 and B6) and antioxidants. cupcakes with cocoa showed similar trend in their nutrient values with slightly increases. The highest cakes volume and specific volume were noticed in sample 6 ( $34 \mathrm{~g}$ millet flour $+34 \mathrm{~g}$ rice flour $+32 \mathrm{~g}$ rice starch) and sample 12 (34g millet flour $+34 \mathrm{~g}$ rice flour $+32 \mathrm{~g}$ rice starch $+2 \mathrm{~g}$ cocoa). These increases could be attributed to those samples containing rice starch which exhibited an important role for the gelatinization process that led to high volume. Regarding the color values (crust and crumb) of cupcakes without and with cocoa, data showed that samples 2 and $8(100 \%$
\end{abstract}




\section{Enayat M. Hassan, Hany A. Fahmy, Shimaa Magdyand Magda I. Hassan*}

millet flour) decreased in lightness and increased redness and yellowness of

cakes. This may be due to the addition of cocoa that distinctive in dark color. Similarity of preference of mothers and children with celiac disease for the same cupcake samples. Therefore, this work achieved the goal by making acceptable gluten-free cupcakes using available raw materials with appropriate nutritional value for celiac disease patients.

\section{Introduction}

Celiac disease $(C D)$ is a hereditary autoimmune disease where it is a global health problem(Wang and Hopper, 2014and Singh et al., 2018). People with celiac disease are sensitive to gluten, which adversely affects their small intestine and causes inflammation and malabsorption of their food nutrients content (Biagi et al., 2018).Therefore, a lifelong diet of gluten-free products is vital for them. However, gluten-free products are prohibitively expensive for most celiac patients (Feizollahi et al., 2018 and Lindfors et al., 2019).The increasing number of people intolerant to gluten or with celiac disease has caused an increase in demand for gluten-free products, along with rising efforts to improve the quality of gluten-free products in the market, which designed to mimic the quality attributes of wheat bakery products (Nicolae et al., 2016).

Cakes are one of the most popular and common bakery products which consumed by people all over the world. Wheat flour is the most important ingredient in cake. Wheat gluten gives viscoelastic property and is answerable for the final structure of bakery products. Nowadays, it must be looking for different products 
Egyptian J. of Nutrition Vol. XXXV No. 1 (2020)

free gluten with high nutritional value for celiac patients (AgraharMurugkar etal., 2018).

Pearl millet is one of the most important cereal crop, grown mostly in marginal environments in the arid and semi-arid tropical regions(Sharma, 2015).Millets are good sources of energy, protein, fatty acids, minerals, vitamins and polyphenols (Azarbad et al., 2019). It contains a high proportion of soluble dietary fiber and could be tapped for hypocholesterolemic, hypoglycemic, chronic diseases such as colorectal cancer and obesity (Lestienne et al., 2007; Shahidi and Chandrasekara, 2013 and Kaur et al., 2019). It is a desirable ingredient for producing gluten-free products, because it is considered as gluten-free cereal (Nandini et al., 2019).

Rice flour is a cheap nutrient source, which often used in gluten-free baking. It has a desirable taste, white color and good nutritional value (Nazni and Gracia, 2014 and Witczak et al., 2016). Rice has hypoallergenic properties for low content of prolamin, which makes it a good candidate for food substitution among celiac disease patients(Liu et al., 2017). Also, corn flour is useful since it lacks gluten. It has a good nutritional value which contains high amounts of easily digested carbohydrates, protein, fat and minerals, so, it is desirable grains for celiac diets(Al Shehry, 2016 and Josiane et al., 2017).

Hydrocolloids are substances that are used as additives for reproducing similar viscoelastic properties to the gluten. Xanthan gum is added to naturally gluten-free flours to mimic the viscoelastic properties of gluten for improving structure, sensory attributes and shelf-life of the bakery products (Aly and Seleem, 2015 and Dizlek and Ozer, 2016).Addition of gum to the cake formulation leads to light weight values, retrogradation enthalpy andthe change in setback 


\section{Enayat M. Hassan, Hany A. Fahmy, Shimaa Magdyand Magda I. Hassan*}

viscosity of the cakes, meaning that staling was retarded (Sumnu et al., 2010).

\section{Aim of this study}

The main objective of this study was to make acceptable gluten-free cupcakes using available raw materials with appropriate nutritional value for celiac disease patients.

\section{Materials and Methods}

\section{Materials:}

Pearl millet grains (Pennisetum americanum), var. Shandawel-1 was obtained from the Feed Crop Department, Crop Research Institute, Agricultural ResearchCentre,Giza, Egypt. Corn and rice flours, rice starch, sugar, salt, baking powder, fresh eggs, vanilla, cocoa and corn oil were purchased from the local markets, Giza, Egypt. Sodium stearoyl lactylate emulsifier (SSL)were supplied by Cornell laboratory, Cairo, Egypt. All chemicals (analytical grade) were purchased from Sigma-Aldrich Chemical Co., Egypt.

\section{Methods:}

Pearl millet grains were cleaned to remove any impurities and damaged grains as well as foreign matters by hand picking and ground into flour to pass through 60 mesh sieve, then packed in polyethylene bags and kept at $-18^{\circ} \mathrm{C}$ for analysis and preparing cupcakes.

\section{Preparation of cupcakes}

Cupcakes were prepared according to the method described by AACC (2012) with some modifications. Ingredients for making cupcake formulas are shown in Table (1). 
Egyptian J. of Nutrition Vol. XXXV No. 1 (2020)

Different cupcakes without or with cocoa were prepared by adding sugar, corn oil and sodium stearoyl lactylate emulsifier (SSL).

The ingredients were creamed for $10 \mathrm{~min}$. using a handheld electric mixer, eggs and vanilla mixed for $4 \mathrm{~min}$. The dry materials (flours, salt, baking powder and cocoa) in the case of cocoa cupcake were sifted together, water added, the batter mixed for $3 \mathrm{~min}$. and poured into bake cups paper then baked at $180^{\circ} \mathrm{C}$ for $35 \mathrm{~min}$. The cakes were cooled for $15 \mathrm{~min}$. and packed into polyethylene bags until analysis.

\section{Analytical Methods}

\section{Chemical analysis:}

Moisture, protein, fat, crude fibers and ash, of cupcake samples were determined according to AOAC (2012). Total carbohydrates were calculated by difference. The minerals $(\mathrm{Ca}, \mathrm{P}, \mathrm{K}$, $\mathrm{Mg}, \mathrm{Na}, \mathrm{Fe}, \mathrm{Zn}, \mathrm{Cu}$ and $\mathrm{Mn}$ ) were determined by using atomic absorption spectrophotometer (model 3300, Perkin-Elimer, Beaconsfield, UK) according to the method described in $A O A C$ (2010). $B$ complex vitamins $\left(B_{1}, B_{2}, B_{6}\right.$, niacin and folic acid) were estimated by the method of Batifoulier et al. (2005), while vitamins $A$ and E were estimated according to the method described by Plozza et al. (2012)by using HPLC (Agilant technologies, Germany).

\section{Antioxidant profile:}

Antioxidant activity was determined by using DPPH-radical scavenging activity following the method reported by Oms-Oliu et al. (2009). Determination of total phenolic contents were carried out by the Folin-Ciocalteu reagent according to the method of Sahu and Saxena (2013) and the results were expressed as $\mathrm{mg}$ gallic acid equivalents per $100 \mathrm{~g}$ (mg GAE / $100 \mathrm{~g}$ ), while the total flavonoids were measured spectrophotometrically according to the method of 


\section{Enayat M. Hassan, Hany A. Fahmy, Shimaa Magdyand Magda I. Hassan*}

Sahu and Saxena (2013).The results were expressed as $\mathrm{mg}$ quercetin equivalents (QE) per $100 \mathrm{~g}$ of the sample (mg quercetin /100 g).

\section{Physical properties:}

The volume $(\mathrm{cm} 3)$ and the weight $(\mathrm{g})$, were recorded after cooling for $1 \mathrm{hr}$, by the method of AACC (2012). Specific volume $(\mathrm{cm} / \mathrm{g})$ and Density $(\mathrm{g} / \mathrm{cm} 3)$ were calculated. Crust and crumb color were determined according to the method described in AACC (2012) by using spectrophotometer (MOM, 100D, Hungary).

\section{Sensory evaluation:}

Ten mothers of children (25-43 years) with celiac disease in out-patient clinic of Abu Rish Children Hospital, Cairo, were asked to evaluate twelve samples (6 samples with cocoa and 6 samples without cocoa) for sensory quality attributes [appearance (15), crust color (15), crumb color (15), texture (15), odor (20), taste (20), and overall acceptability (100)] according to the procedure of Khorshid et al., (2011). After the statistical analysis, the most acceptable cupcakes by mothers were offered to 20 celiac disease children (9-11 years) for choosing their favorite samples. The hedonic scale questionnaire was carried out by children (satisfied, neutral and unsatisfied), by watching their facial feature during tasting each sample and asking them about their preference and admiration of cupcakes.

\section{Statistical Analysis}

The collected data were analyzed by the analysis of variance (ANOVA) and least significant differences (L.S.D) at 0.05 level using 
Egyptian J. of Nutrition Vol. XXXV No. 1 (2020)

Costat Statistical Software, 1990. Mean and standard deviation are also calculated.

\section{Results and Discussion}

\section{Chemical composition}

The presented data in Table (2) showed that the highest protein content was noticed in sample (2) $(100 \%$ millet flour) followed by sample (4) $(50 \%$ millet flour $+50 \%$ rice flour) compared to the remaining samples. This may be ascribed to the high protein content of millet flour. Data showed that the higher fat contents were found in samples (2) followed by sample (1) (control) then sample (4), and sample (3) while the samples 5 and 6 have a reasonable amounts. Significant differences were noticed among all the samples and their control in all macro-nutrient contents. The sample 3 (100\% rice flour) showed lower protein, fat, ash and fiber compared with those in the control. These results are in harmony with findings of Hussein et al. (2012) who indicated that rice flour and cakes produced from it contained lower percentage of protein $5.91 \%$, fat $5.02 \%$, ash $1.56 \%$ and $0.62 \%$ fiber and higher content in total carbohydrates $86.89 \%$.

Concerning minerals content, data in Table (2) showed that the sample (2) (100\% millet flour) had higher content of $\mathrm{Ca}, \mathrm{P}, \mathrm{K}$, $\mathrm{Mg}, \mathrm{Fe}, \mathrm{Zn}$ and $\mathrm{Cu}(97.55,420.38,337.58,189.54,12.57,6.25$ and $1.06 \mathrm{mg} / 100 \mathrm{~g}$, respectively), followed by sample (5) (67 g millet flour $+33 \mathrm{~g}$ rice starch) in the same parameters $(91.85,382.84,321.95$, $168.34,9.94,5.86$ and $0.93 \mathrm{mg} / 100 \mathrm{~g}$, respectively) than the other samples.

It could be noticed that cupcake sample (2) recorded increasing in all vitamins except riboflavin and folic acid $(0.28$ and $28.97 \mathrm{mg} / 100 \mathrm{~g}$, consecutively) in comparison with the control $(100 \%$ 


\section{Enayat M. Hassan, Hany A. Fahmy, Shimaa Magdyand Magda I. Hassan*}

corn flour). It could be observed that the cupcakes containing millet flour showed high vitamin contents in most samples, this may be ascribed to the high nutrients in millet flour compared to rice or corn flours. These results are in agreement with those obtained by Mehra and Singh (2017) who indicated that the pearl millet had high content of minerals and vitamins.

It could be observed from the tabulated results in Table (3) that the cupcakes with cocoa showed a similar trend in nutrient values of samples with slightly increasing compared with the values of their counterparts of cake without cocoa (Tables, 2). This confirms that adding cocoa powder slightly increased the most of nutrients. In this concern, Campos-Vega et al. (2018) reported that cocoa powder is considered rich sources of dietary fibers, minerals such as magnesium, calcium and potassium as well as vitamins $A, E, B$ and folic acid.

Data pertaining in Fig (1) illustrated that the antioxidants profile of the cupcake without cocoa recorded the highest DPPH $(63.78 \%)$ in cupcake sample $2(100 \%$ millet flour), total phenolic component (TPC) was expressed as $482.78 \mathrm{mg}$ GAE /100 g, while total flavonoid (TFC) was $85.95 \mathrm{mg}$ quercetien $/ 100 \mathrm{~g}$ followed by sample 5 (67g millet flour $+33 \mathrm{~g}$ rice starch), then sample 4 ( $50 \mathrm{~g}$ millet flour $+50 \mathrm{~g}$ rice flour) compared to the control and sample 6 while sample 3 was the lowest. This may be attributed to addition of pearl millet which was higher in both total phenols and flavonoids. In this concern, pearl millet is rich in phenolic acids and total antioxidants with higher levels than those found in traditional grains such as rice and maize(Dias-martins et al., 2018).Meanwhile, similar trend was detected in cocoa cupcakes the counterparts of those 


\section{Egyptian J. of Nutrition Vol. XXXV No. 1 (2020)}

without cocoa (Fig. 2) with partially increases in the antioxidant values. This finding may be ascribed to the addition of cocoa powder. However, the lowest antioxidants values were clear in samples 3 and 9 because of their main component being rice flour (100\% rice). These results are in line with the previous study reported by Campos-Vega et al. (2018)who indicated that cocoa powder is a rich source of phenols, flavones and subsequently antioxidant potential.

\section{Physical Properties}

Higher quality cakes are associated to light weight, spongy structure, high volume and low density. Starch gelatinization and protein denaturation together with carbon dioxide formation give cake its porous and soft structure (Agrahar-Murugkar et al., 2018). It could be noticed from Fig. 3and 4 that the highest cakes volume and specific volume were noted in samples 6 , followed by sample 5 then sample 1 of cake without cocoa while the lowest was found in sample 2. On the other hand, appreciable increases in volume and specific volume of cocoa cakes were noticed in samples 12, 11 and the control compared to the others. In this concern, Agrahar-Murugkar et al. (2018)reported that higher specific volume due to unique foaming, leavening, and heat coagulation properties of egg proteins and water vaporization during baking. Additional, these increases inthe abovementioned samples could be attributed to those samples containing rice starch which it has an important role for the gelatinization process that leads to high volume.

On the contrary, samples 2 and 8 showed the lowest volume and specific volume which contained $100 \%$ millet flour. Starch plays an important role in gluten-free products (Yang, 2016), gelatinization of starch is vital to build structure, texture (Gallagher et al., 2004)and prevent staling (Witczak et al., 2016). 


\section{Enayat M. Hassan, Hany A. Fahmy, Shimaa Magdyand Magda I. Hassan *}

\section{Color properties}

Color is one of the most important sensory characteristics that affect directly the consumer acceptance of any product. Special attention should be given to bakery products to attract the consumer attention (Krupa-Kozak et al., 2019).

Color measurements of the cupcake without or with cocoa are illustrated in Tables, 4 and 5 . It is noteworthy that $L$ value is expressed the lightness. The high $L$ values of crust cupcakes without cocoa could be arranged in descending order as follows: 52.94, 49.26, 43.19 and 42.76 in control (1) and samples 3,6, 4, respectively. However, sample 5 and 2 showed the lowest $L$ values, indicating significant increases in grayish color (low light). This may be attributed to the color of millet added with high amounts of the cakes. The (b) value revealed that a positive value (yellow hue) for all the evaluated samples. The control (100\% corn) showed a significantly higher crust (b) value than that of the other samples. These values indicated that cupcakes containing $100 \%$ corn had the lightness and yellowness color. While those contained millet showed low values. In this regard, Ranasalva and Visvanathan (2014)clarified in their study that the pearl millet had increased in Lvalues shifted significantly from white to gray, a-values shifted from green to red, and b-values shifted from blue to yellow.

Concerning the values of crumb, data in Table (4) revealed that the crumb color of sample2 ( $100 \%$ millet flour) was darker than all samples, where lightness $(L)$ and yellowness values (b) decreased when millet flour used in cake processing. Meanwhile, sample 4 showed highest values of crumb redness (a) followed by samples 5 


\section{Egyptian J. of Nutrition Vol. XXXV No. 1 (2020)}

then 2 compared to the others and their control. Unfortunately, millet is rich in all nutrients but has an undesirable effect on cake color.

From other side, the results in Table (5) showed that the addition of cocoa powder to the cakes led to darker color than that of counterpart cakes without cocoa. Similar trend was noticed in the values of color measurements ( $L, b$ and $a$ ) of both crust and crumb of cocoa cakes and those of cake without cocoa with slightly decreases in the color values. This may be due to the addition of cocoa that distinctive in dark color. In this concern, the chromaticity coordinate a-value increased in line with the increased substitution of cocoa powder, and the chromaticity coordinate b-value decreased in the same manner (Rosa et al., 2015).

\section{Sensory evaluation}

The sensory evaluation of cupcake samples (with or without cocoa) was carried out in two stages, the first stage was done by the mothers of children with celiac disease. Table (6) revealed that all tested gluten-free cupcakes without cocoa got over than $90 \%$ as overall acceptability. The most acceptable samples was sample6 $(96.8 \%)$ (34g millet flour $+34 \mathrm{~g}$ rice flour $+32 \mathrm{~g}$ rice starch) which significantly had the highest scores for all evaluated attributes, followed by sample $4(96.1 \%)$ then the control (94.5\%). On the contrary, the acceptability of sample (2) (100\% millet flour) was lower than the samples 6 and 4 while it is near to the control. Significant differences were found among the sample (6) and all samples for the sensory attributes except the appearance, crumb color and texture of sample (4). The second stage started after statistical analysis of cupcakes which showed that the most acceptable samples by the mothers (with highly perception) were three [Control (100\% corn flour), sample (4) ( $50 \mathrm{~g}$ millet flour $+50 \mathrm{~g}$ rice flour) and sample $6(34 \mathrm{~g}$ 


\section{Enayat M. Hassan, Hany A. Fahmy, Shimaa Magdyand Magda I. Hassan*}

millet flour $+34 \mathrm{~g}$ rice flour $+32 \mathrm{~g}$ rice starch)]. These samples were offered to the children in the out- patient clinic, Abu-Rish children hospital to choose the most acceptable and favorite taste by using a hedonic scale questionnaire (satisfied, neutral and unsatisfied).

Data presented in Table (6) indicated that $60 \%$ of kids with celiac disease were satisfied for sample (6) which got their admiration, while $10 \%$ of them were unsatisfied whilst $30 \%$ were neutral for this sample. On the contrary, $65 \%$ of children were unsatisfied for the control sample. Meanwhile, sample (4) was accepted by $25 \%$ of children (satisfied), however $50 \%$ of them were neutral compared to the control. It could be concluded that two samples ( 6 and 4 ) exhibited more acceptability by kids. It is may be attributed to their content of millet and rice flours.

The same trend was noticed in cocoa cupcakes and those cupcake samples without cocoa with slightly increases in their score values of sensory attributes. No significant differences were observed between sample12 and sample 10 for of crust color, crumb color and odor, also between samples 12 and 8 for the crumb color, texture and odor. On the other hand, the percentage of satisfied kids was $70 \%$ for sample 12 , followed by $40 \%$ of sample 10 , while they recorded 15 $\%$ for the control. It could be concluded that the addition of cocoa improved the most sensory attributes of cakes which reflect the admiration among most of the children. 
Egyptian J. of Nutrition Vol. XXXV No. 1 (2020)

\section{Conclusion}

Cake is one of the most popular bakery products. The cupcake (with or without cocoa) prepared with $100 \%$ millet flour had higher contents of protein, fat, ash, $\mathrm{Ca}, \mathrm{Fe}, \mathrm{Zn}$, and vitamins (A, E, B1, B3 and B6) as well as antioxidant potency than other samples. Meanwhile, their sensory scores of such samples were low due to their low specific volume and dark color where they exhibited significant increases in L-value which was shifted significantly from white to gray, also, a-value was shifted from green to red, b-value was shifted from blue to yellow. Sensory evaluation showed that sample $6(96.8 \%$ ) (34g millet flour $+34 \mathrm{~g}$ rice flour $+32 \mathrm{~g}$ rice starch) was the most acceptable sample. These cakes may be beneficial for celiac children due to its high nutritive value and in the same time they are gluten-free. 


\section{Enayat M. Hassan, Hany A. Fahmy, Shimaa Magdyand Magda I. Hassan*}

Table 1. Ingredients of cupcake formulas

\begin{tabular}{l|c|c|c|c|c|c|c|c|c|c|c|c}
\hline \multirow{2}{*}{ Ingredients (g) } & \multicolumn{4}{|c|}{ Without cocoa } & \multicolumn{3}{c|}{ Formulas $^{*}$} & \multicolumn{5}{c}{ With cocoa } \\
\cline { 2 - 15 } & 1 & 2 & 3 & 4 & 5 & 6 & 7 & 8 & 9 & 10 & 11 & 12 \\
\hline Corn flour & 100 & - & - & - & - & - & 100 & - & - & - & - & - \\
\hline Millet flour & - & 100 & - & 50 & 67 & 34 & - & 100 & - & 50 & 67 & 34 \\
\hline Rice flour & - & - & 100 & 50 & - & 34 & - & - & 100 & 50 & - & 34 \\
\hline Rice starch & - & - & - & - & 33 & 32 & - & - & - & - & 33 & 32 \\
\hline Cocoa & - & - & - & - & - & - & 2 & 2 & 2 & 2 & 2 & 2 \\
\hline
\end{tabular}

${ }^{*}$ Cupcake formulas contain the same amounts of $10 \mathrm{~g}$ baking powder, $100 \mathrm{~g} \mathrm{egg}, 1 \mathrm{~g}$ vanilla,

$90 \mathrm{~g}$ sugar, $40 \mathrm{ml}$ oil, $2 \mathrm{~g} \mathrm{SSL}, 0.5 \mathrm{~g}$ salt, $50 \mathrm{ml}$ water.

1: Control without cocoa

7: Control with cocoa 
Egyptian J. of Nutrition Vol. XXXV No. 1 (2020)

Table 2. Chemical composition of cupcake samples without cocoa (ondry weight basis)

\begin{tabular}{|c|c|c|c|c|c|c|}
\hline \multirow{2}{*}{$\begin{array}{c}\text { Chemical } \\
\text { composition }\end{array}$} & \multicolumn{6}{|c|}{ Samples } \\
\hline & 1 & 2 & 3 & 4 & 5 & 6 \\
\hline Protein (\%) & $11.45^{\mathrm{c}} \pm 0.03$ & $14.87^{\mathrm{a}} \pm 0.02$ & $10.32^{f} \pm 0.05$ & $13.97^{b} \pm 0.01$ & $11.19^{\mathrm{d}} \pm 0.02$ & $10.82^{\mathrm{e}} \pm 0.02$ \\
\hline Fat (\%) & $19.65^{b} \pm 0.02$ & $20.52^{\mathrm{a}} \pm 0.04$ & $17.43^{\mathrm{d}} \pm 0.02$ & $18.87^{\mathrm{c}} \pm 0.05$ & $15.44^{\mathrm{e}} \pm 0.03$ & $13.13^{\mathrm{f}} \pm 0.04$ \\
\hline Total Ash (\%) & $3.05^{\mathrm{b}} \pm 0.03$ & $3.30^{\mathrm{a}} \pm 0.05$ & $2.04^{f} \pm 0.02$ & $2.70^{\mathrm{d}} \pm 0.05$ & $2.86^{c} \pm 0.04$ & $2.57^{\mathrm{e}} \pm 0.05$ \\
\hline Crude Fiber(\%) & $1.52^{\mathrm{a}} \pm 0.02$ & $1.35^{\mathrm{b}} \pm 0.03$ & $0.25^{\mathrm{e}} \pm 0.03$ & $0.92^{\mathrm{d}} \pm 0.05$ & $1.04^{\mathrm{c}} \pm 0.03$ & $0.96^{\mathrm{d}} \pm 0.04$ \\
\hline Carbohydrate(\%) & $64.33^{\mathrm{d}} \pm 0.01$ & $59.96^{\mathrm{f}} \pm 0.01$ & $69.96^{\mathrm{b}} \pm 0.05$ & $63.54^{\mathrm{e}} \pm 0.01$ & $69.47^{c} \pm 0.05$ & $72.52^{\mathrm{a}} \pm 0.05$ \\
\hline Moisture (\%) & $23.01^{\mathrm{a}} \pm 0.05$ & $18.48^{\mathrm{d}} \pm 0.04$ & $20.81^{b} \pm 0.03$ & $19.56^{c} \pm 0.01$ & $14.17^{\mathrm{f}} \pm 0.01$ & $15.79^{\mathrm{e}} \pm 0.05$ \\
\hline \multicolumn{7}{|c|}{ Minerals (mg/100g) } \\
\hline $\mathrm{Ca}$ & $78.35^{\mathrm{d}} \pm 0.08$ & $97.55^{\mathrm{a}} \pm 0.58$ & $72.85^{\mathrm{f}} \pm 0.24$ & $88.2^{\mathrm{c}} \pm 0.54$ & $91.85^{b} \pm 0.48$ & $75.97^{\mathrm{e}} \pm 0.07$ \\
\hline $\mathrm{P}$ & $359.25^{\mathrm{d}} \pm 0.48$ & $420.38^{\mathrm{a}} \pm 0.29$ & $229.57^{\mathrm{f}} \pm 0.09$ & $365.25^{c} \pm 0.24$ & $382.84^{\mathrm{b}} \pm 0.12$ & $246.25^{\mathrm{e}} \pm 0.46$ \\
\hline $\mathrm{K}$ & $299.57^{\mathrm{d}} \pm 0.08$ & $337.58^{\mathrm{a}} \pm 0.17$ & $133.69^{f} \pm 0.09$ & $218.45^{\mathrm{c}} \pm 0.04$ & $321.95^{b} \pm 0.23$ & $153.74^{\mathrm{e}} \pm 0.15$ \\
\hline $\mathrm{Mg}$ & $93.28^{\mathrm{d}} \pm 0.06$ & $189.54^{\mathrm{a}} \pm 0.53$ & $36.87^{f} \pm 0.05$ & $113.07^{c} \pm 0.17$ & $168.34^{\mathrm{b}} \pm 0.27$ & $79.71^{\mathrm{e}} \pm 0.19$ \\
\hline $\mathrm{Na}$ & $101.84^{\mathrm{a}} \pm 0.21$ & $70.43^{\mathrm{c}} \pm 0.35$ & $72.42^{\mathrm{b}} \pm 0.74$ & $70.18^{\mathrm{c}} \pm 0.69$ & $67.6^{\mathrm{e}} \pm 0.37$ & $69.94^{\mathrm{d}} \pm 0.48$ \\
\hline $\mathrm{Fe}$ & $8.81^{\mathrm{d}} \pm 0.14$ & $12.57^{\mathrm{a}} \pm 0.09$ & $5.34^{\mathrm{f}} \pm 0.05$ & $9.04^{\mathrm{c}} \pm 0.09$ & $9.94^{\mathrm{b}} \pm 0.10$ & $6.14^{\mathrm{e}} \pm 0.08$ \\
\hline $\mathrm{Zn}$ & $3.93^{\mathrm{d}} \pm 0.09$ & $6.25^{\mathrm{a}} \pm 0.07$ & $2.9^{f} \pm 0.06$ & $4.55^{c} \pm 0.08$ & $5.86^{\mathrm{b}} \pm 0.12$ & $3.57^{\mathrm{e}} \pm 0.07$ \\
\hline $\mathrm{Cu}$ & $0.57^{\mathrm{f}} \pm 0.12$ & $1.06^{\mathrm{a}} \pm 0.17$ & $0.89^{\mathrm{c}} \pm 0.05$ & $0.74^{\mathrm{d}} \pm 0.07$ & $0.93^{\mathrm{b}} \pm 0.09$ & $0.61^{\mathrm{e}} \pm 0.05$ \\
\hline $\mathrm{Mn}$ & $5.12^{\mathrm{d}} \pm 0.05$ & $5.04^{\mathrm{d}} \pm 0.09$ & $20.35^{\mathrm{a}} \pm 0.21$ & $12.59^{\mathrm{b}} \pm 0.07$ & $3.31^{\mathrm{e}} \pm 0.05$ & $8.62^{c} \pm 0.08$ \\
\hline \multicolumn{7}{|c|}{ Vitamins (mg/100g) } \\
\hline Vit. A & $40.44^{c} \pm 0.35$ & $46.42^{\mathrm{a}} \pm 0.32$ & $45.03^{\mathrm{b}} \pm 0.74$ & $46.01^{\mathrm{ab}} \pm 0.62$ & $46.66^{\mathrm{a}} \pm 0.22$ & $46.78^{\mathrm{a}} \pm 0.13$ \\
\hline Vit. E & $0.81^{b c} \pm 0.11$ & $1.17^{\mathrm{a}} \pm 0.14$ & $0.43^{\mathrm{d}} \pm 0.04$ & $0.79^{b c} \pm 0.05$ & $0.86^{\mathrm{b}} \pm 0.06$ & $0.64^{c} \pm 0.03$ \\
\hline Thiamine (B1) & $0.30^{\mathrm{b}} \pm 0.15$ & $0.39^{\mathrm{a}} \pm 0.02$ & $0.08^{\mathrm{f}} \pm 0.79$ & $0.23^{\mathrm{d}} \pm 0.05$ & $0.26^{\mathrm{c}} \pm 0.02$ & $0.16^{\mathrm{e}} \pm 0.03$ \\
\hline Riboflavin (B2) & $0.21^{c} \pm 0.03$ & $0.28^{\mathrm{b}} \pm 0.02$ & $0.04^{\mathrm{d}} \pm 0.03$ & $0.30^{\mathrm{ab}} \pm 0.06$ & $0.33^{\mathrm{a}} \pm 0.02$ & $0.26^{\mathrm{bc}} \pm 0.03$ \\
\hline Niacin (B3) & $1.64^{\mathrm{f}} \pm 0.07$ & $6.45^{\mathrm{a}} \pm 0.37$ & $1.70^{\mathrm{e}} \pm 0.21$ & $3.21^{\mathrm{c}} \pm 0.23$ & $4.27^{\mathrm{b}} \pm 0.07$ & $3.02^{\mathrm{d}} \pm 0.08$ \\
\hline Pyridoxine (B6) & $0.09^{\mathrm{e}} \pm 0.04$ & $2.71^{\mathrm{a}} \pm 0.14$ & $0.05^{\mathrm{f}} \pm 0.03$ & $1.5^{c} \pm 0.28$ & $1.81^{\mathrm{b}} \pm 0.12$ & $0.95^{\mathrm{d}} \pm 0.03$ \\
\hline Folic acid & $31.57^{\mathrm{a}} \pm 0.26$ & $28.97^{b} \pm 0.38$ & $14.51^{\mathrm{f}} \pm 0.11$ & $21.82^{\mathrm{d}} \pm 0.07$ & $23.93^{\mathrm{c}} \pm 0.20$ & $20.16^{\mathrm{e}} \pm 0.06$ \\
\hline
\end{tabular}

Means $(n=3)$ in the same row with different letters are significantly different $(p<0.05)$.

Sample 1: The control (100g Corn), Sample 2: (100g Millet), Sample 3: (100g Rice), Sample 4: $(50 \mathrm{~g}$ Millet $+50 \mathrm{~g}$ Rice), Sample 5: $(67 \mathrm{~g}$ Millet $+33 \mathrm{~g}$ Rice Starch), Sample $6:(34 \mathrm{~g}$ Millet $+34 \mathrm{~g}$ Rice+ 32g Rice Starch). 


\section{Enayat M. Hassan, Hany A. Fahmy, Shimaa Magdyand Magda I. Hassan *}

Table 3. Chemical composition of cupcake samples with cocoa (on dry weight basis)

\begin{tabular}{|c|c|c|c|c|c|c|}
\hline \multirow{2}{*}{$\begin{array}{c}\text { Chemical } \\
\text { composition }\end{array}$} & \multicolumn{6}{|c|}{ Samples } \\
\hline & 7 & 8 & 9 & 10 & 11 & 12 \\
\hline Protein (\%) & $12.09^{\mathrm{c}} \pm 0.04$ & $15.28^{\mathrm{a}} \pm 0.05$ & $10.80^{f} \pm 0.03$ & $14.46 \pm 0.08$ & $11.70^{\mathrm{d}} \pm 0.05$ & $11.48^{\mathrm{e}} \pm 0.03$ \\
\hline Fat (\%) & $19.96^{\mathrm{b}} \pm 0.05$ & $20.91^{\mathrm{a}} \pm 0.05$ & $17.74^{\mathrm{d}} \pm 0.04$ & $18.85^{\mathrm{c}} \pm 0.03$ & $15.72^{\mathrm{e}} \pm 0.04$ & $13.56^{\mathrm{f}} \pm 0.02$ \\
\hline Ash (\%) & $3.37^{\mathrm{b}} \pm 0.02$ & $3.50^{\mathrm{a}} \pm 0.01$ & $2.33^{\mathrm{f}} \pm 0.05$ & $3.11^{\mathrm{d}} \pm 0.02$ & $3.25^{c} \pm 0.03$ & $3.07^{\mathrm{e}} \pm 0.05$ \\
\hline Fiber (\%) & $1.55^{\mathrm{a}} \pm 0.02$ & $1.29^{\mathrm{b}} \pm 0.04$ & $0.30^{\mathrm{e}} \pm 0.05$ & $0.99^{\mathrm{d}} \pm 0.04$ & $1.09^{c} \pm 0.02$ & $1.01^{\mathrm{d}} \pm 0.04$ \\
\hline Carbohydrate(\%) & $63.03^{\mathrm{d}} \pm 0.04$ & $59.02^{f} \pm 0.02$ & $68.83^{b} \pm 0.05$ & $62.59^{\mathrm{e}} \pm 0.06$ & $68.24^{\mathrm{c}} \pm 0.04$ & $70.88^{a} \pm 0.05$ \\
\hline Moisture (\%) & $23.44^{\mathrm{a}} \pm 0.04$ & $18.57^{\mathrm{d}} \pm 0.03$ & $20.94^{\mathrm{b}} \pm 0.01$ & $19.81^{\mathrm{c}} \pm 0.05$ & $14.25^{\mathrm{f}} 0.04$ & $15.85^{\mathrm{e}} \pm 0.04$ \\
\hline \multicolumn{7}{|c|}{ Minerals (mg/100g) } \\
\hline $\mathrm{Ca}$ & $84.85^{\mathrm{d}} \pm 0.06$ & $100.22^{\mathrm{a}} \pm 0.42$ & $77.85^{\mathrm{f}} \pm 0.12$ & $89.09^{c} \pm 0.68$ & $94.41^{\mathrm{b}} \pm 0.42$ & $80.97^{\mathrm{e}} \pm 0.05$ \\
\hline$P$ & $314.25^{\mathrm{d}} \pm 0.53$ & $425.66^{\mathrm{a}} \pm 0.24$ & $246.05^{\mathrm{f}} \pm 0.04$ & $340.25^{\mathrm{c}} \pm 0.28$ & $387.71^{\mathrm{b}} \pm 0.16$ & $261.37^{\mathrm{e}} \pm 0.45$ \\
\hline K & $227.03^{\mathrm{d}} \pm 0.04$ & $345.18^{\mathrm{a}} \pm 0.12$ & $140.75^{f} \pm 0.06$ & $325.93^{c} \pm 0.02$ & $338.95^{\mathrm{b}} \pm 0.26$ & $161.22^{\mathrm{e}} \pm 0.16$ \\
\hline $\mathrm{Mg}$ & $84.26^{\mathrm{d}} \pm 0.02$ & $190.57^{\mathrm{a}} \pm 0.47$ & $37.47^{f} \pm 0.07$ & $114.15^{\mathrm{c}} \pm 0.09$ & $129.24^{\mathrm{b}} \pm 0.25$ & $65.61^{\mathrm{e}} \pm 0.16$ \\
\hline $\mathrm{Na}$ & $102.87^{\mathrm{a}} \pm 0.12$ & $70.97^{\mathrm{c}} \pm 0.30$ & $73.04^{\mathrm{b}} \pm 0.71$ & $70.5^{c} \pm 0.70$ & $68.14^{\mathrm{e}} \pm 0.31$ & $69.84^{d} \pm 0.56$ \\
\hline $\mathrm{Fe}$ & $8.45^{\mathrm{d}} \pm 0.04$ & $12.84^{\mathrm{a}} \pm 0.07$ & $5.57^{\mathrm{f}} \pm 0.04$ & $9.04^{c} \pm 0.15$ & $9.51^{b} \pm 0.07$ & $6.34^{\mathrm{e}} \pm 0.07$ \\
\hline $\mathrm{Zn}$ & $3.97^{\mathrm{d}} \pm 0.02$ & $6.27^{\mathrm{a}} \pm 0.04$ & $3.04^{\mathrm{f}} \pm 0.07$ & $5.09^{c} \pm 0.04$ & $5.90^{b} \pm 0.09$ & $3.59^{\mathrm{e}} \pm 0.04$ \\
\hline $\mathrm{Cu}$ & $0.59^{\mathrm{f}} \pm 0.03$ & $1.11^{\mathrm{a}} \pm 0.10$ & $0.85^{c} \pm 0.07$ & $0.79^{\mathrm{d}} \pm 0.05$ & $0.98^{\mathrm{b}} \pm 0.04$ & $0.64^{\mathrm{e}} \pm 0.03$ \\
\hline Mn & $5.19^{d} \pm 0.06$ & $5.11^{\mathrm{d}} \pm 0.10$ & $20.42^{\mathrm{a}} \pm 0.29$ & $12.66^{\mathrm{b}} \pm 0.14$ & $3.38^{e} \pm 0.07$ & $8.69^{c} \pm 0.06$ \\
\hline \multicolumn{7}{|c|}{ Vitamins (mg/100g) } \\
\hline Vit. A & $44.48^{c} \pm 0.42$ & $46.45^{\mathrm{a}} \pm 0.38$ & $45.08^{\mathrm{b}} \pm 0.81$ & $46.03^{b} \pm 0.54$ & $46.67^{\mathrm{a}} \pm 0.32$ & $46.80^{\mathrm{a}} \pm 0.21$ \\
\hline Vit. E & $1.04^{b c} \pm 0.08$ & $1.37^{\mathrm{a}} \pm 0.09$ & $0.60^{\mathrm{d}} \pm 0.07$ & $0.91^{b c_{ \pm}} \pm 0.04$ & $1.06^{\mathrm{b}} \pm 0.08$ & $0.89^{c} \pm 0.05$ \\
\hline Thiamine ( $\mathrm{B}_{1}$ ) & $0.39^{\mathrm{b}} \pm 0.14$ & $0.50^{\mathrm{a}} \pm 0.19$ & $0.19^{\mathrm{f}} \pm 0.04$ & $0.35^{\mathrm{d}} \pm 0.16$ & $0.37^{c} \pm 0.18$ & $0.25^{\mathrm{e}} \pm 0.12$ \\
\hline Riboflavin $\left(\mathrm{B}_{2}\right)$ & $0.55^{c} \pm 0.07$ & $0.59^{\mathrm{b}} \pm 0.05$ & $0.33^{d} \pm 0.04$ & $0.65^{a b} \pm 0.05$ & $0.69^{\mathrm{a}} \pm 0.07$ & $0.56^{b c} \pm 0.03$ \\
\hline Niacin $\left(B_{3}\right)$ & $1.86^{\mathrm{f}} \pm 0.13$ & $6.69^{\mathrm{a}} \pm 0.24$ & $1.95^{\mathrm{e}} \pm 0.19$ & $3.46^{\mathrm{c}} \pm 0.21$ & $4.40^{\mathrm{b}} \pm 0.05$ & $3.23^{\mathrm{d}} \pm 0.07$ \\
\hline Pyridoxine (B6) & $0.20^{\mathrm{e}} \pm 0.10$ & $2.80^{\mathrm{a}} \pm 0.18$ & $0.18^{\mathrm{f}} \pm 0.14$ & $1.69^{c} \pm 0.09$ & $1.99^{\mathrm{b}} \pm 0.05$ & $1.02^{\mathrm{d}} \pm 0.013$ \\
\hline Folic acid & $31.69^{\mathrm{a}} \pm 0.24$ & $29.09^{b} \pm 0.29$ & $14.67^{\mathrm{f}} \pm 0.14$ & $21.98^{\mathrm{d}} \pm 0.24$ & $24.09^{c} \pm 0.21$ & $20.28^{\mathrm{e}} \pm 0.29$ \\
\hline
\end{tabular}

Means $(n=3)$ in the same row with different letters are significantly different $(p<0.05)$.

Sample 7: The control ( $100 \mathrm{~g}$ Corn $+2 \mathrm{~g}$ Cocoa), Sample 8: $(100 \mathrm{~g}$ Millet $+2 \mathrm{~g}$ Cocoa), Sample 9: (100g Rice $+2 \mathrm{~g}$ Cocoa), Sample 10:(50g Millet+ 50g Rice $+2 \mathrm{~g}$ Cocoa),Sample 11: $(67 \mathrm{~g}$ Millet $+33 \mathrm{~g}$ Rice Starch $+2 \mathrm{~g}$ Cocoa), Sample 12: $(34 \mathrm{~g}$ Millet $+34 g$ Rice $+32 g$ Rice Starch $+2 g$ Cocoa) 
Egyptian J. of Nutrition Vol. XXXV No. 1 (2020)

Table 4. Color measurements of cupcake samples without cocoa

\begin{tabular}{c|c|c|c|c|c|c|c}
\hline \multirow{2}{*}{ Samples } & \multicolumn{7}{|c}{ Color measurements } \\
\cline { 2 - 8 } & $\mathrm{L}$ & $\mathrm{a}$ & $\mathrm{b}$ & Hue & Chroma & $\Delta \mathrm{E}$ & $\mathrm{BI}$ \\
\hline Crust & & & & & & \\
\hline 1 & $52.94^{\mathrm{a}}$ & $8.10^{\mathrm{f}}$ & $30.72^{\mathrm{a}}$ & $15.88^{\mathrm{e}}$ & $29.60^{\mathrm{b}}$ & $60.66^{\mathrm{a}}$ & $59.75^{\mathrm{e}}$ \\
\hline 2 & $34.90^{\mathrm{f}}$ & $14.17^{\mathrm{c}}$ & $16.72^{\mathrm{f}}$ & $41.45^{\mathrm{a}}$ & $22.31^{\mathrm{e}}$ & $44.20^{\mathrm{f}}$ & $62.44^{\mathrm{c}}$ \\
\hline 3 & $49.26^{\mathrm{b}}$ & $11.67^{\mathrm{e}}$ & $28.47^{\mathrm{b}}$ & $13.10^{\mathrm{f}}$ & $30.77^{\mathrm{a}}$ & $58.33^{\mathrm{b}}$ & $56.84^{\mathrm{f}}$ \\
\hline 4 & $42.76^{\mathrm{d}}$ & $18.06^{\mathrm{a}}$ & $22.92^{\mathrm{d}}$ & $35.89^{\mathrm{c}}$ & $30.80^{\mathrm{a}}$ & $46.55^{\mathrm{e}}$ & $70.88^{\mathrm{a}}$ \\
\hline 5 & $38.15^{\mathrm{e}}$ & $14.77^{\mathrm{b}}$ & $19.14^{\mathrm{e}}$ & $36.50^{\mathrm{b}}$ & $23.82^{\mathrm{d}}$ & $48.94^{\mathrm{d}}$ & $61.50^{\mathrm{d}}$ \\
\hline 6 & $43.19^{\mathrm{c}}$ & $13.41^{\mathrm{d}}$ & $24.95^{\mathrm{c}}$ & $30.33^{\mathrm{d}}$ & $26.56^{\mathrm{c}}$ & $50.70^{\mathrm{c}}$ & $67.29^{\mathrm{b}}$ \\
\hline \multicolumn{7}{|c|}{ Crumb }
\end{tabular}

\begin{tabular}{c|c|c|c|c|c|c|c}
\hline 1 & $58.97^{\mathrm{a}}$ & $3.77^{\mathrm{f}}$ & $29.85^{\mathrm{a}}$ & $7.62^{\mathrm{f}}$ & $30.12^{\mathrm{a}}$ & $34.71^{\mathrm{f}}$ & $31.88^{\mathrm{e}}$ \\
\hline 2 & $46.65^{\mathrm{f}}$ & $8.67^{\mathrm{c}}$ & $24.85^{\mathrm{f}}$ & $20.03^{\mathrm{b}}$ & $26.45^{\mathrm{c}}$ & $37.31^{\mathrm{d}}$ & $30.51^{\mathrm{b}}$ \\
\hline 3 & $52.47^{\mathrm{b}}$ & $3.99^{\mathrm{e}}$ & $26.41^{\mathrm{b}}$ & $18.17^{\mathrm{c}}$ & $27.80^{\mathrm{b}}$ & $36.11^{\mathrm{e}}$ & $37.57^{\mathrm{c}}$ \\
\hline 4 & $49.45^{\mathrm{d}}$ & $10.26^{\mathrm{a}}$ & $25.49^{\mathrm{d}}$ & $21.75^{\mathrm{a}}$ & $27.69^{\mathrm{b}}$ & $38.52^{\mathrm{b}}$ & $32.34^{\mathrm{a}}$ \\
\hline 5 & $48.31^{\mathrm{e}}$ & $9.06^{\mathrm{b}}$ & $25.13^{\mathrm{e}}$ & $14.17^{\mathrm{d}}$ & $26.29^{\mathrm{d}}$ & $38.08^{\mathrm{c}}$ & $35.26^{\mathrm{d}}$ \\
\hline 6 & $49.80^{\mathrm{c}}$ & $6.44^{\mathrm{d}}$ & $25.72^{\mathrm{c}}$ & $8.72^{\mathrm{e}}$ & $25.52^{\mathrm{e}}$ & $39.13^{\mathrm{a}}$ & $30.77^{\mathrm{f}}$ \\
\hline
\end{tabular}

Means $(n=3)$ in the same column with different letters are significantly different $(p<0.05)$.

Sample 1: The control (100g Corn), Sample 2: (100g Millet), Sample 3: (100g Rice), Sample 4:(50g Millet $+50 \mathrm{~g}$ Rice), Sample 5: (67g Millet $+33 \mathrm{~g}$ Rice Starch), Sample 6:

(34g Millet +34g Rice+ 32g Rice Starch). 


\section{Enayat M. Hassan, Hany A. Fahmy, Shimaa Magdyand Magda I. Hassan *}

Table 5. Color measurements of cupcakes with cocoa

\begin{tabular}{l|c|c|c|c|c|c|c}
\hline \multirow{2}{*}{$\begin{array}{c}\text { Sampl } \\
\text { es }\end{array}$} & \multicolumn{6}{c}{ Color measurements } \\
\cline { 2 - 8 } Crust & $\mathrm{L}$ & $\mathrm{a}$ & $\mathrm{b}$ & Hue & Chroma & $\Delta \mathrm{E}$ & $\mathrm{BI}$ \\
\hline 7 & $39.36^{\mathrm{a}}$ & $14.63^{\mathrm{f}}$ & $11.52^{\mathrm{a}}$ & $63.23^{\mathrm{b}}$ & $18.04^{\mathrm{f}}$ & $34.46^{\mathrm{d}}$ & $54.06^{\mathrm{f}}$ \\
\hline 8 & $26.76^{\mathrm{f}}$ & $16.90^{\mathrm{c}}$ & $8.11^{\mathrm{f}}$ & $64.29^{\mathrm{a}}$ & $18.76^{\mathrm{c}}$ & $32.92^{\mathrm{e}}$ & $58.71^{\mathrm{c}}$ \\
\hline 9 & $38.66^{\mathrm{b}}$ & $16.11^{\mathrm{e}}$ & $11.38^{\mathrm{b}}$ & $64.24^{\mathrm{a}}$ & $22.37^{\mathrm{a}}$ & $37.15^{\mathrm{c}}$ & $66.13^{\mathrm{a}}$ \\
\hline 10 & $34.35^{\mathrm{d}}$ & $20.14^{\mathrm{a}}$ & $8.77^{\mathrm{d}}$ & $61.47^{\mathrm{c}}$ & $18.37^{\mathrm{e}}$ & $32.46^{\mathrm{f}}$ & $59.37^{\mathrm{b}}$ \\
\hline 11 & $27.06^{\mathrm{e}}$ & $17.03^{\mathrm{b}}$ & $8.14^{\mathrm{e}}$ & $51.80^{\mathrm{e}}$ & $18.62^{\mathrm{d}}$ & $39.08^{\mathrm{b}}$ & $54.35^{\mathrm{e}}$ \\
\hline 12 & $35.33^{\mathrm{c}}$ & $16.14^{\mathrm{d}}$ & $9.72^{\mathrm{c}}$ & $56.25^{\mathrm{d}}$ & $20.49^{\mathrm{b}}$ & $40.84^{\mathrm{a}}$ & $57.28^{\mathrm{d}}$ \\
\hline 7 & & & & \multicolumn{7}{|c}{$\mathrm{Crumb}^{\mathrm{b}}$} & & \\
\hline 8 & $24.99^{\mathrm{f}}$ & $16.79^{\mathrm{c}}$ & $9.69^{\mathrm{f}}$ & $48.48^{\mathrm{f}}$ & $14.87^{\mathrm{f}}$ & $53.63^{\mathrm{f}}$ & $66.64^{\mathrm{c}}$ \\
\hline 9 & $33.17^{\mathrm{b}}$ & $16.72^{\mathrm{e}}$ & $13.74^{\mathrm{b}}$ & $66.18^{\mathrm{a}}$ & $23.98^{\mathrm{a}}$ & $59.38^{\mathrm{b}}$ & $73.96^{\mathrm{a}}$ \\
\hline 10 & $32.00^{\mathrm{d}}$ & $21.49^{\mathrm{a}}$ & $11.86^{\mathrm{d}}$ & $50.14^{\mathrm{e}}$ & $21.44^{\mathrm{c}}$ & $55.68^{\mathrm{e}}$ & $66.23^{\mathrm{d}^{\mathrm{y}}}$ \\
\hline 11 & $26.99^{\mathrm{e}}$ & $18.32^{\mathrm{b}}$ & $11.52^{\mathrm{e}}$ & $53.51^{\mathrm{d}}$ & $20.10^{\mathrm{e}}$ & $56.00^{\mathrm{c}}$ & $60.66^{\mathrm{f}}$ \\
\hline 12 & $32.35^{\mathrm{c}}$ & $16.45^{\mathrm{d}}$ & $12.30^{\mathrm{c}}$ & $53.66^{\mathrm{c}}$ & $20.75^{\mathrm{d}}$ & $55.96^{\mathrm{d}}$ & $61.54^{\mathrm{e}}$ \\
\hline
\end{tabular}

Means $(n=3)$ in the same column with different letters are significantly different $(p<0.05)$.

Sample 7: The control (100g Corn $+2 \mathrm{~g}$ Cocoa), Sample 8: (100g Millet $+2 \mathrm{~g}$ Cocoa), Sample 9:

(100g Rice+2g Cocoa), Sample 10:(50g Millet $+50 \mathrm{~g}$ Rice $+2 \mathrm{~g}$ Cocoa), Sample 11: (67g Millet +33g Rice Starch $+2 g$ Cocoa), Sample 12: (34g Millet $+34 g$ Rice and 32g Rice Starch $+2 \mathrm{~g}$ Cocoa) . 
Egyptian J. of Nutrition Vol. XXXV No. 1 (2020)

Table 6. Sensory evaluation of cupcakes without cocoa by mothers, and hedonic scale (\%)by children with celiac disease

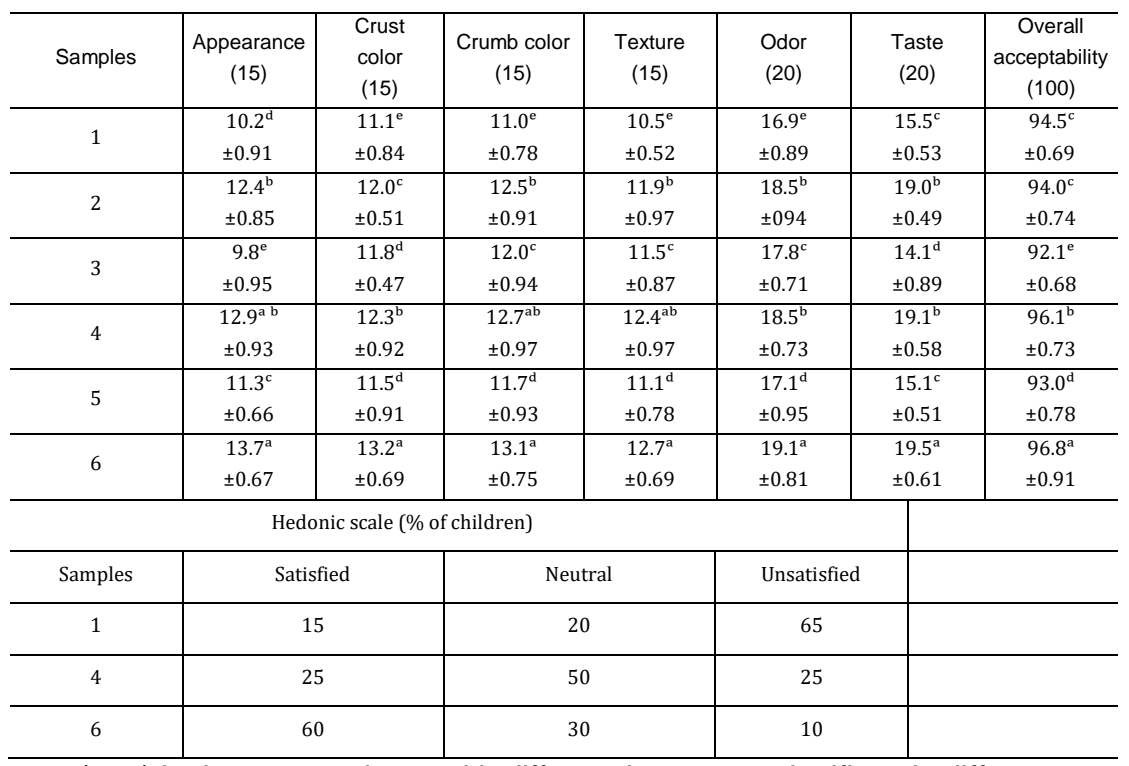

Means $(n=3)$ in the same column with different letters are significantly different $(p<0.05)$.

Sample 1: The control (100g Corn), Sample 2: (100g Millet), Sample 3: (100g Rice), Sample 4: ( $50 \mathrm{~g}$ Millet $+50 \mathrm{~g}$ Rice),

Sample 5: (67g Millet $+33 g$ Rice Starch), Sample 6: (34g Millet $+34 g$ Rice+ 32g Rice Starch). 


\section{Enayat M. Hassan, Hany A. Fahmy, Shimaa Magdyand Magda I. Hassan*}

Table 7. Sensory evaluation of cupcake with cocoa by mothers, and hedonic scale(\%) by children with celiac disease

\begin{tabular}{|c|c|c|c|c|c|c|c|}
\hline Samples & $\begin{array}{c}\text { Appearance } \\
\text { (15) }\end{array}$ & $\begin{array}{c}\text { Crustcolor } \\
\text { (15) }\end{array}$ & $\begin{array}{c}\text { Crumb color } \\
\text { (15) }\end{array}$ & $\begin{array}{c}\text { Texture } \\
\text { (15) }\end{array}$ & $\begin{array}{l}\text { Odor } \\
(20)\end{array}$ & $\begin{array}{c}\text { Taste } \\
(20)\end{array}$ & $\begin{array}{c}\text { Overall } \\
\text { acceptability } \\
(100)\end{array}$ \\
\hline 7 & $12.5^{\mathrm{d}} \pm 0.68$ & $13.2^{\mathrm{b}} \pm 0.71$ & $12.2^{\mathrm{d}} \pm 0.98$ & $12.9^{c} \pm 0.88$ & $17.9^{\mathrm{b}} \pm 0.89$ & $17.8^{\mathrm{d}} \pm 0.93$ & $93.8^{c} \pm 0.99$ \\
\hline 8 & $13.2^{\mathrm{b}} \pm 0.98$ & $13.5^{\mathrm{b}} \pm 0.81$ & $13.5^{\mathrm{ab}} \pm 0.71$ & $13.9^{\mathrm{a}} \pm 0.74$ & $18.5^{\mathrm{ab}} \pm 0.64$ & $18.2^{\mathrm{c}} \pm 0.89$ & $93.3^{c} \pm 0.59$ \\
\hline 9 & $12.9^{\mathrm{c}} \pm 0.95$ & $11.9^{\mathrm{d}} \pm 0.94$ & $13.0^{\mathrm{b}} \pm 0.63$ & $11.6^{\mathrm{d}} \pm 0.97$ & $17.9^{\mathrm{b}} \pm 0.85$ & $16.5^{\mathrm{e}} \pm 0.91$ & $90.7^{\mathrm{e}} \pm 0.95$ \\
\hline 10 & $13.5^{\mathrm{b}} \pm 0.83$ & $14.0^{\mathrm{ab}} \pm 0.72$ & $13.7^{\mathrm{a}} \pm 0.87$ & $13.5^{\mathrm{b}} \pm 0.77$ & $18.3^{\mathrm{ab}} \pm 0.93$ & $18.7^{\mathrm{b}} \pm 0.98$ & $94.9^{\mathrm{b}} \pm 0.97$ \\
\hline 11 & $12.0^{\mathrm{e}} \pm 0.86$ & $12.5^{\mathrm{c}} \pm 0.97$ & $12.7^{\mathrm{c}} \pm 0.98$ & $11.5^{\mathrm{d}} \pm 0.92$ & $17.5^{\mathrm{bc}} \pm 0.81$ & $16.3^{\mathrm{e}} \pm 0.69$ & $92.5^{\mathrm{d}} \pm 0.79$ \\
\hline 12 & $14.1^{\mathrm{a}} \pm 0.57$ & $14.5^{\mathrm{a}} \pm 0.99$ & $13.9^{\mathrm{a}} \pm 0.85$ & $14.0^{\mathrm{a}} \pm 0.79$ & $18.8^{\mathrm{a}} \pm 0.51$ & $19.1^{\mathrm{a}} \pm 0.85$ & $95.8^{\mathrm{a}} \pm 0.87$ \\
\hline \multicolumn{8}{|c|}{ Hedonic scale ( $\%$ of children) } \\
\hline $\begin{array}{c}\text { Samp } \\
\text { les }\end{array}$ & \multicolumn{2}{|c|}{ Satisfied } & \multicolumn{2}{|l|}{ Neutral } & Unsatisfied & & \\
\hline 7 & \multicolumn{2}{|c|}{15} & \multicolumn{2}{|l|}{40} & 45 & & \\
\hline 10 & \multicolumn{2}{|c|}{40} & \multicolumn{2}{|l|}{55} & 5 & & \\
\hline 12 & \multicolumn{2}{|c|}{70} & \multicolumn{2}{|l|}{30} & 0 & & \\
\hline
\end{tabular}

Means $(n=3)$ in the same column with different letters are significantly different $(p<0.05)$.

Sample 7: The control (100g Corn $+2 \mathrm{~g}$ Cocoa), Sample 8: (100g Millet $+2 \mathrm{~g}$ Cocoa), Sample 9: (100g Rice $+2 \mathrm{~g}$ Cocoa), Sample 10: $(50 \mathrm{~g}$ Millet $+50 \mathrm{~g}$

Rice $+2 \mathrm{~g}$ Cocoa), Sample 11: $(67 \mathrm{~g}$ Millet $+33 \mathrm{~g}$ Rice Starch $+2 \mathrm{~g}$ Cocoa), Sample $12:(34 \mathrm{~g}$ Millet $+34 g$ Rice and $32 g$ Rice Starch $+2 g$ Cocoa). 
Egyptian J. of Nutrition Vol. XXXV No. 1 (2020) 
Enayat M. Hassan, Hany A. Fahmy, Shimaa Magdyand Magda I. Hassan* 
Egyptian J. of Nutrition Vol. XXXV No. 1 (2020)

\section{References}

AACC. (2012).

Approved methods of the american association of cereal chemists, St. Paul, MN, USA.

Agrahar-Murugkar, D., Zaidi, A., and Dwivedi, S. (2018).

Development of gluten free eggless cake using gluten free composite flours made from sprouted and malted ingredients and its physical, nutritional, textural, rheological and sensory properties evaluation. J. Food Sci. Technol., 55(7), 26212630.

Al Shehry, G. A. (2016).

Use of corn and quinoa flour to produce bakery products for celiac disease. Adv. Environ. Biol., 10, 237-244.

Aly, M. M. A., and Seleem, H. A. (2015).

Gluten-free flat bread and biscuits production by cassava, extruded soy protein and pumpkin powder. Food Nutr. Sci.,6(7), 660-674.

AOAC. (2010).

Official Methods of Analysis, $18^{\text {th }}$ Ed., Association of official analyticalchemistsinternational; Revision 3; Gaithersburg, Maryland; USA. 


\section{Enayat M. Hassan, Hany A. Fahmy, Shimaa Magdyand Magda I. Hassan*}

AOAC. (2012).

Official Methods of Analysis, $19^{\text {th }}$ Ed., Association of official analytical chemists international; Gaithersburg, Maryland; USA.

Azarbad, H. R., Mazaheri Tehrani, M., and Rashidi, H. (2019). Optimization of gluten-free bread formulation using sorghum, rice, and millet flour by D-optimal mixture design approach.J. Agric. Sci. Technol.,21(1),101-115.

Batifoulier, F., Verny, M., Besson, C., and Demign, C. (2005).

Determination of thiamine and its phosphate esters in rat tissues analyzed as thiochromes on a RP-amide C16 column. J. Chem.,816, 67-72.

Biagi, F., Raiteri, A., Schiepatti, A., Klersy, C., and Corazza, G. R. (2018).

The relationship between child mortality rates and prevalence of celiac disease. J. Pediatr. Gastroenterol. Nutr., 66(2), 289294.

Campos-Vega, R., Nieto-Figueroa, K. H., and Oomah, B. D. (2018).

Cocoa (Theobroma cacao L.) pod husk: Renewable source of bioactive compounds. Trends Food Sci. Technol.,81, 172184. 
Egyptian J. of Nutrition Vol. XXXV No. 1 (2020)

Dias-martins, A. M., Pessanha, K. L., Rodrigues, J. A. S., and Piler, C. W. (2018).

Potential use of pearl millet (Pennisetum glaucum (L.) R. Br.) in Brazil: food security, processing, health benefits and nutritional products. Food Res. Int.,4,111-120. https://doi.org/10.1016/j.foodres.2018.04.023

Dizlek, H., and Ozer, M. S. (2016).

The impacts of various ratios of different hydrocolloids and surfactants on quality characteristics of corn starch based gluten-free bread. Cereal Res. Commun., 44(2), 298-308.

Feizollahi, E., Mirmoghtadaie, L., Mohammadifar, M. A., Jazaeri, S., Hadaegh, H., Nazari, B., and Lalegani, S. (2018). Sensory, digestion and texture quality of commercial glutenfree bread: impact of broken rice flour type (In press). J. Text. Stud., 395-403. https://doi.org/10.1111/jtxs.12326

Gallagher, E., Gormley, T. R., and Arendt, E. K. (2004).

Recent advances in the formulation of gluten-free cerealbased products. Trends Food Sci. Technol., 15(3-4), 143152.

Hussein, A. M. S., Hegazy, N. A., and Ibrahim, T. A. A. (2012).

Production and evaluation of gluten-free cakes. Aust. J. Basic and Appl. Sci., 6(12), 482-491. 
Enayat M. Hassan, Hany A. Fahmy, Shimaa Magdyand Magda I. Hassan *

Josiane, S. A., Bienvenu, A. V., Wilfried, P. S., Adolphe, A., Djima, A., Joachin, G., and Lamine, B. M. (2017).

Nutritional properties assessment of endogenous and improved varieties of maize (Zea mays L.) grown in southern benin. Pakistan J. Biol. Sci.,20(6), 267-277.

Kaur, P., Singh, S., Singh, K., Maninder, S., Raj, K., and Salar, K. (2019).

Millets: A cereal grain with potent antioxidants and health benefits millets. J. Food Measurement Characterization, 13(1), 793-806.

Khorshid, A. M., Assem, N. H. A., Nadia, M., and Fahim, J. S. (2011).

Utilization of flaxseeds in improving bread quality. EgyptJ.Agric.Res., 89(1), 241-250.

Krupa-Kozak, U., Drabińska, N., Rosell, C. M., Fadda, C., Anders, A., Jeliński, T., and Ostaszyk, A. (2019).

Broccoli leaf powder as an attractive by-product ingredient: Effect on batter behaviour, technological properties and sensory quality of gluten-free mini sponge cake. Int. J. Food Sci. Technol., 54(4), 1121-1129. https://doi.org/10.1111/ijfs.13972 
Egyptian J. of Nutrition Vol. XXXV No. 1 (2020)

Lestienne, I., Buisson, M., Lullien-Pellerin, V., Picq, C., and Trèche, S. (2007).

Losses of nutrients and anti-nutritional factors during abrasive decortication of two pearl millet cultivars (Pennisetum glaucum). Food Chem., 100(4), 1316-1323.

Lindfors, K., Ciacci, C., Kurppa, K., Lundin, K. E. A., Makharia, G. K., Mearin, L. M., Murray, J. A., Verdu, E. F., and Kaukinen, K. (2019).

Coeliac disease. Primer, 5-18.

https://doi.org/10.1038/s41572-018-0054-z

Liu, C. K., Chen, C. A., Lee, T. Y., Chang, H. H., Liao, H. F., and Chen, Y. J. (2017).

Rice protein prolamin promotes anti-leukemia immunity and inhibits leukemia growth in vivo. Food Chem. Toxicol.,112, $435-440$.

Mehra, A., and Singh, U. (2017).

Development, organoleptic and nutritional evaluation of pearl millet based mathri. Int. J. Recent Sci. Res., 8(6), 1793917942.

Nandini, N., Bhasker, V., and Maloo, S. (2019). Development and quality evaluation of wafers incorporated with pearl millet flour and sorghum millet flour. Int. J. Food Sci. Nutr., 4(1), 9-15. 


\section{Enayat M. Hassan, Hany A. Fahmy, Shimaa Magdyand Magda I. Hassan*}

Nazni, P., and Gracia, J. (2014).

Application of response surface methodology in the development of barnyard millet bran incorporated bread.Int. J. Innov. Res. Sci. Eng. Technol., 03(09), 16041-16048.

Nicolae, A., Radu, G. L., and Belc, N. (2016).

Effect of sodium carboxymethyl cellulose on gluten-free dough rheology. J. Food Eng.,168, 16-19.

Oms-Oliu, G., Odriozola-Serrano, I., Soliva-Fortuny, R., and Martín-Belloso, O. (2009).

Effects of high-intensity pulsed electric field processing conditions on lycopene, vitamin $\mathrm{C}$ and antioxidant capacity of watermelon juice. Food Chem., 115(4), 1312-1319.

Plozza, T., Trenerry, V. C., and Caridi, D. (2012).

The simultaneous determination of vitamins $A, E$ and $b$ carotene in bovine milk by high performance liquid chromatography - ion trap mass spectrometry ( HPLC - MS ). Food Chem., 134(1), 559-563.

Ranasalva, N., and Visvanathan, R. (2014).

Development of bread from fermented pearl millet flour. J. Food Process Technol., 5(5), 1-5. 
Egyptian J. of Nutrition Vol. XXXV No. 1 (2020)

Rosa, C. S., Tessele, K., Prestes, R. C., Silveira, M., and Franco, F. (2015).

Effect of substituting of cocoa powder for carob flour in cakes made with soy and banana flours. Int. Food Res. J., 22(5), 2111-2118.

Sahu, R., and Saxena, J. (2013).

Screening of total phenolic and flavonoid content in conventional and non-conventional species of curcuma.J. Pharmacogn. Phytochem.,2(1),176-179.

Shahidi, F., and Chandrasekara, A. (2013).

Millet grain phenolics and their role in disease risk reduction and health promotion: A review. J. Funct. Foods, 5(2), 570581.

Sharma, B. (2015).

Biochemical Characterization of Pearl Millet [ Pennisetum glaucum ( L . ) R . B r . ] Genotypes for Identifying Off - Odour Factors, Ph.D. Thesis, Haryana Agricultural University, Haryana.

Singh, P., Arora, A., Strand, T. A., Leffler, k D. A., Catassi, C., Green, P. H., Kelly, C. P., Vineet Ahuja, A., and Makharia, G. K. (2018).

Global prevalence of celiac disease: Systematic review and meta-analysis. Clin. Gastroenterol. Hepatol., 16(6), 823-836. 
Enayat M. Hassan, Hany A. Fahmy, Shimaa Magdyand Magda I. Hassan *

Sumnu, G., Koksel, F., Sahin, S., Basman, A., and Meda, V. (2010).

The effects of xanthan and guar gums on staling of glutenfree rice cakes baked in different ovens. Int. J. Food Sci. Technol., 45(1), 87-93.

Wang, I., and Hopper, I. (2014).

Celiac disease and drug absorption: Implications for cardiovascular therapeutics. Cardiovasc. Ther., 32(6), 253256.

Witczak, M., Ziobro, R., Juszczak, L., and Korus, J. (2016).

Starch and starch derivatives in gluten-free systems - A review. J.Cereal Sci., 67(2015), 46-57.

Yang, T. (2016).

Development of Gluten - Free Wrap Bread. M.SC. Thesis, Massey University, Albany, New Zealand. 
Egyptian J. of Nutrition Vol. XXXV No. 1 (2020)

الخصائص الفيزيائية والكيميائية والحسية للكب كيك الخالي من الجلوتين

\section{* .ـد/ عنايات محمود حسن , ** ا.د/ هانئ عبد العزيز فهمى , * ب.م/ شيماء مجدى , * د/ ماجده ابراهيم حسن}

*قمم علوم الاغذيةـ كليةالزر اعة - جامعة القاهرهـ الجيزة - مصر

**قم الاغذيه الخاصه و التغذيه ـ معهد بحوث تكنولوجيا الاغذيه ــ مركز

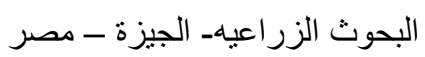

\section{الملخص العربي}

تتزايد الحاجة هذه الايام إلى منتجات المخابز الخالية من الجلوتين. لذا ، كان الهدف من هذه الدر اسة هو انتاج كب كيك خالي من الجلوتين ومقبو لا من الناحية الحسية باستخدام دقيق الدخن اللؤلؤى و الأرز و الذرة للمرضى المصـابين بحساسية الجلوتين. "قيمتالصفات الكيمائيسة و المضـادة

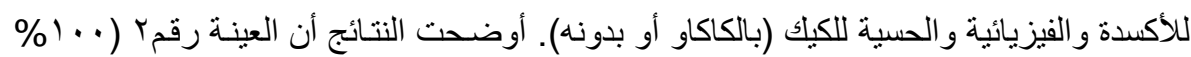
دقيق الدخن) كانت أعلى العينات فى الدحتوي من البروتين و الدهون و الرماد و الكالسيوم و الحديد و الزنك و الفيتامينات (أ، ه، بr، بـ) ومضادات الأكسدة. وأظهرتعينات الكب كيك بالكاكاو إتجاه

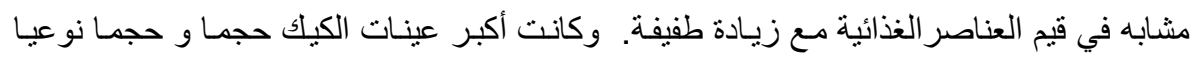

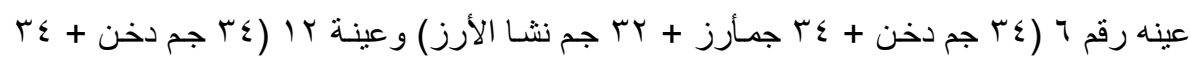

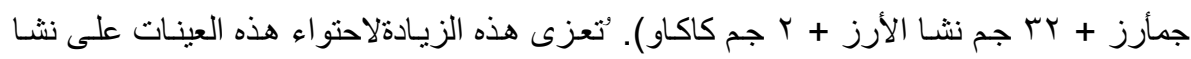
الأرز الذى له دور هام في عملية الجلتنة التي تؤدي إلى زياده الحجم. فيما يتعلق بقيم اللون (القشرة

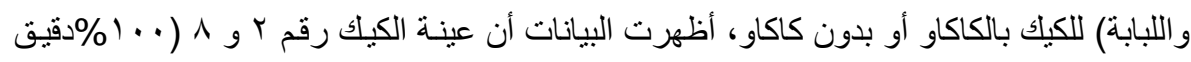
الدخن ) كانت اقل سطو عا وزياده فى درجه احمرار و اصفرار الكيك. وقد يكون هذا بسبب إضافة الكاكاو الذي يتميز بلونه الداكن. لوحظ فى التقييم الحسى تشـابه تفضيل الأمهات والأطفال لعينات 
Enayat M. Hassan, Hany A. Fahmy, Shimaa Magdyand Magda I. Hassan *

الكيك. لذلك، فإن هذا العمل حقق الهدف منهمن خـلال عمل كيك خالي من الجلوتين مقبول حسيا باستخدام المو اد الخام المتاحة و ذوقيمة غذائية مناسبة لمرضى الحساسية ضد الجلوتين. 